\title{
Occupations at risk of contracting zoonoses of public health significance in Québec
}

\author{
Ariane Adam-Poupart 1,2,3*, Laurie-Maude Drapeau' ${ }^{1}$, Sadjia Bekal ${ }^{4}$, Geneviève Germain ${ }^{1,5}$, \\ Alejandra Irace-Cima ${ }^{1,2}$, Marie-Pascale Sassine ${ }^{1}$, Audrey Simon ${ }^{3,5}$, Julio Soto ${ }^{1,2}$, Karine Thivierge ${ }^{4,6}$, \\ France Tissot $^{1}$
}

\begin{abstract}
Introduction: Climate change plays an important role in the geographic spread of zoonotic diseases. Knowing which populations are at risk of contracting these diseases is critical to informing public health policies and practices. In Québec, 14 zoonoses have been identified as important for public health to guide the climate change adaptation efforts of decision-makers and researchers. A great deal has been learned about these diseases in recent years, but information on at-risk workplaces remains incomplete. The objective of this study is to paint a portrait of the occupations and sectors of economic activity at risk for the acquisition of these zoonoses.
\end{abstract}

Methods: A rapid review of the scientific literature was conducted. Databases on the Ovid and EBSCO research platforms were searched for articles published between 1995 and 2018, in English and French, on 14 zoonoses (campylobacteriosis, cryptosporidiosis, verocytotoxigenic Escherichia coli, giardiasis, listeriosis, salmonellosis, Eastern equine encephalitis, Lyme disease, West Nile virus, food botulism, Q fever, avian and swine influenza, rabies, hantavirus pulmonary syndrome) and occupational health. The literature search retrieved 12,558 articles and, after elimination of duplicates, 6,838 articles were evaluated based on the title and the abstract. Eligible articles had to address both concepts of the research issue (prioritized zoonoses and worker health). Of the 621 articles deemed eligible, 110 were selected following their full reading.

Results: Of the diseases under study, enteric zoonoses were the most frequently reported. Agriculture, including veterinary services, public administration services and medical and social services were the sectors most frequently identified in the literature.

Conclusion: The results of our study will support public health authorities and decision-makers in targeting those sectors and occupations that are particularly at risk for the acquisition of zoonoses. Doing so will ultimately optimize the public health practices of those responsible for the health of workers.

Suggested citation: Adam-Poupart A, Drapeau LM, Bekal S, Germain G, Irace-Cima A, Sassine MP, Simon A, Soto J, Thivierge K, Tissot F. Occupations at risk of contracting zoonoses of public health significance in Québec. Can Commun Dis Rep 2021;47(1):47-58. https://doi.org/10.14745/ccdr.v47i01a08

Keywords: zoonoses, occupations, sectors of activity, workers, public health

\section{Introduction}

Climate change plays an important role in the geographic establishment and spread of zoonoses. Projected variations in temperature and precipitation will influence the survival and spread of zoonotic pathogens, as well as the distribution of their vectors, favouring the spread of these diseases over larger geographic areas and for longer periods (1).
This work is licensed under a Creative Commons Attribution 4.0 International License.

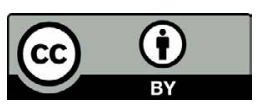

Affiliations

${ }^{1}$ Biological Risks and

Occupational Health Division, Institut national de santé publique du Québec, Québec, QC

2 School of Public Health of the Université de Montréal (ESPUM), Montréal, QC

${ }^{3}$ Research Group on

Epidemiology of Zoonoses and Public Health (GREZOSP), Faculty of Veterinary Medicine (FVM), Université de Montréal,

Montréal, QC

${ }^{4}$ Laboratoire de santé publique du Québec, Institut national de santé publique du Québec, Sainte-Anne-de-Bellevue, OC

${ }^{5}$ Québec's Multi-Party Observatory on Zoonoses and Adaptation to Climate Change

${ }^{6}$ Institute of Parasitology, Faculty of Agricultural and Environmental Sciences, McGill University, Sainte-Anne-de-Bellevue, QC

\section{*Correspondence:}

ariane.adam-poupart@inspq.qc.ca
In Québec, 14 zoonotic diseases were identified as important to public health. Of these, 12 were prioritized by the scientific experts and public policy decision-makers making up Québec's Multi-Party Observatory on Zoonoses and Adaptation to Climate Change. The other two zoonoses are listeriosis and hantavirus pulmonary syndrome (1-3). These 14 zoonoses are enteric (campylobacteriosis, cryptosporidiosis, Shiga toxi-producing 
Escherichia coli, giardiasis, listeriosis, salmonellosis) and non-enteric (vector-borne: Eastern equine encephalitis, Lyme disease, West Nile virus; non-vector-borne: food botulism in Nunavik, Q fever, avian and swine influenza, rabies, hantavirus pulmonary syndrome). The Observatory has published information on populations vulnerable to these diseases, including sealers in Nunavik, who are at risk of acquiring foodborne botulism, and workers in the poultry industry, who are at risk for campylobacteriosis $(2,3)$. However, information targeting workers remains incomplete or even non-existent for some zoonoses, indicating the need to develop this body of knowledge to inform public health policies and practices.

The objective of this study was to identify the occupations and sectors of economic activity most at risk for the acquisition of zoonoses important to public health in Québec in order to contribute to the decision-making process of public health authorities and to optimize the practices of those responsible for workers' health. This synthesis of knowledge from the scientific literature is presented by zoonosis category (enteric, vectorborne non-enteric and non-vector-borne non-enteric).

\section{Methods}

The research team conducted a rapid review of the literature using systematic review methodology. The Ovid and EBSCO platforms were used to search the Medline, Embase, EvidenceBased Medicine Reviews (EBMR), Global Health, Forfait Total Access Collection and Environment Complete databases. The searches of the databases were conducted using a series of keywords related to the zoonoses of interest and to workers' health. Table 1 and Table 2 show the queries developed using these keywords.

The research was restricted to original peer-reviewed studies published between 1995 and 2018, in English or French. Literature reviews, commentaries, editorials, news, letters of opinion and Q\&A were excluded. No restrictions were applied in terms of geographical scope. First, the article was screened by title and abstract; eligible articles had to demonstrate a clear link to the research, i.e. address both concepts of the research issue (prioritized zoonoses and worker health) and minimally address a high-risk sector of economic activity or occupation. Next, a full

\section{Table 1: Queries in Ovid databases}

\begin{tabular}{|c|c|}
\hline $\begin{array}{l}\text { Search } \\
\#\end{array}$ & Requests \\
\hline S1 & $\begin{array}{l}\text { botulism/ or "Clostridium botulinum"/ or "Clostridium botulinum type E"/ or campylobacter/ or "Campylobacter infections"/ or } \\
\text { "Campylobacter jejuni"/ or Cryptosporidiosis/ or exp Cryptosporidium/ or "Encephalitis Virus, Eastern Equine"/ or "Encephalomyelitis, } \\
\text { Eastern Equine"/ or "Shiga-Toxigenic Escherichia coli"/ or "Escherichia coli O157"/ or "Enterohemorrhagic Escherichia coli"/ or "Q } \\
\text { fever"/ or Giardiasis/ or Giardia/ or "Giardia lamblia"/ or exp "Lyme disease"/ or Rabies/ or "Rabies virus"/ or "Salmonella Infections"/ or } \\
\text { "Salmonella Food Poisoning"/ or "Salmonella Infections, Animal"/ or "Salmonella enterica"/ or "Salmonella enteritidis"/ or "Salmonella } \\
\text { typhimurium"/ or "West Nile virus"/ or exp Listeriosis/ or exp Listeria/ or "Hantavirus Infections"/ or "Hantavirus Pulmonary Syndrome"/ }\end{array}$ \\
\hline S2 & $\begin{array}{l}\text { ("Influenza A virus"/ or "Influenza A Virus, H1N1 Subtype"/ or "Influenza A Virus, H1N2 Subtype"/ or "Influenza A Virus, H3N2 Subtype"/ } \\
\text { or "Influenza A Virus, H5N1 Subtype"/ or "Influenza A Virus, H7N9 Subtype"/ or "Influenza in Birds"/) and Zoonoses/ }\end{array}$ \\
\hline S3 & 1 or 2 \\
\hline S4 & 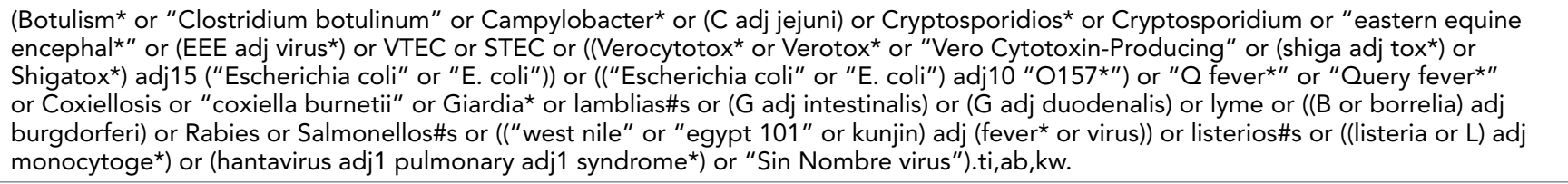 \\
\hline S5 & 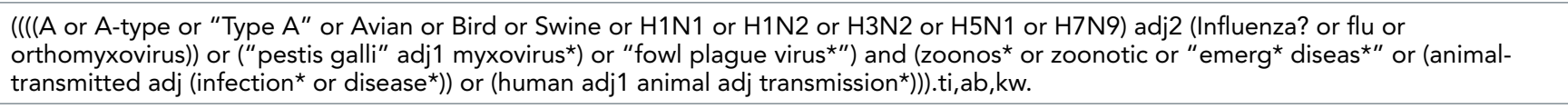 \\
\hline S6 & 4 or 5 \\
\hline S7 & 3 or 6 \\
\hline S8 & $\begin{array}{l}\text { *"occupational exposure"/ or *"occupational health"/ or exp *"occupational groups"/ or *"occupational diseases"/ or *"agricultural } \\
\text { workers' diseases"/ or "meat-packing industry"/ }\end{array}$ \\
\hline S9 & $\begin{array}{l}\text { (occupation* or worker* or workplace* or professional* or employ* or job\$1 or labo?r or labo?rs or labo?rer* or personnel or staff). } \\
\text { ti,ab,kw. }\end{array}$ \\
\hline S10 & (farm* or agricultur* or hunter* or (outdoor adj occupation*) or veterinar* or (wildlife adj manag*) or abattoir* or slaughter*).ti,ab,kw. \\
\hline S11 & 8 or 9 or 10 \\
\hline $\mathrm{S} 12$ & 7 and 11 \\
\hline S13 & 12 not (exp animals/ not humans/) \\
\hline S14 & 13 and (english or french).lg. \\
\hline S15 & limit 14 to $y r=1995-2018$ \\
\hline S16 & 15 not (editorial or letter or comment or news).pt. \\
\hline
\end{tabular}




\section{SCOPING REVIEW}

\section{Table 2: Queries in EBSCO database}

\begin{tabular}{|c|c|}
\hline $\begin{array}{c}\text { Search } \\
\#\end{array}$ & Requests \\
\hline S1 & 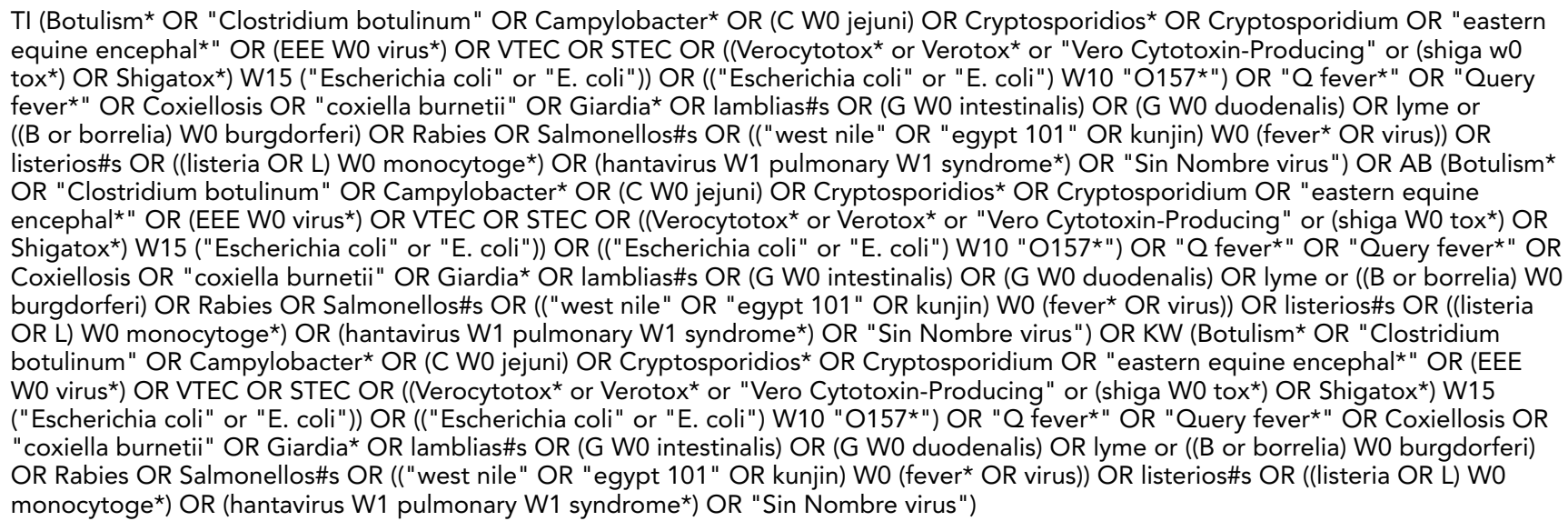 \\
\hline S2 & $\begin{array}{l}\text { TI ((((A OR A-type OR "Type A" OR Avian OR Bird OR Swine OR H1N1 OR H1N2 OR H3N2 OR H5N1 OR H7N9) W2 (Influenza\# OR flu } \\
\text { OR orthomyxovirus)) OR ("pestis galli" W1 myxovirus*) OR "fowl plague virus*") AND (zoonos* OR zoonotic OR "emerg* diseas*" OR } \\
\text { (animal-transmitted W0 (infection* OR disease*)) OR (human W1 animal W0 transmission))) OR AB ((((A OR A-type OR "Type A" OR } \\
\text { Avian OR Bird OR Swine OR H1N1 OR H1N2 OR H3N2 OR H5N1 OR H7N9) W2 (Influenza\# OR flu OR orthomyxovirus)) OR ("pestis } \\
\text { galli" W1 myxovirus*) OR "fowl plague virus*") AND (zoonos* OR zoonotic OR "emerg* diseas*" OR (animal-transmitted W0 (infection* } \\
\text { OR disease )) OR (human W1 animal W0 transmission*))) OR KW ((((A OR A-type OR "Type A" OR Avian OR Bird OR Swine OR H1N1 } \\
\text { OR H1N2 OR H3N2 OR H5N1 OR H7N9) W2 (Influenza\# OR flu OR orthomyxovirus)) OR ("pestis galli" W1 myxovirus*) OR "fowl plague } \\
\text { virus*") AND (zoonos* OR zoonotic OR "emerg* diseas*" OR (animal-transmitted W0 (infection* OR disease*)) OR (human W1 animal W0 } \\
\text { transmission*))) }\end{array}$ \\
\hline S3 & S1 OR S2 \\
\hline S4 & 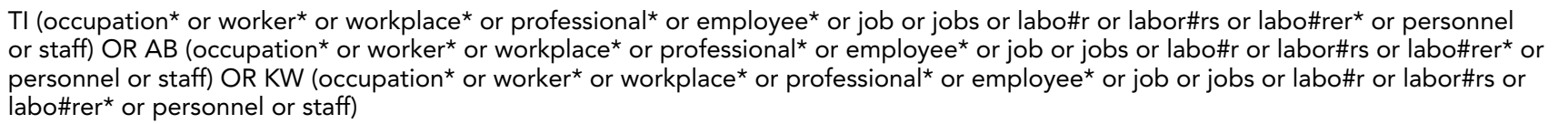 \\
\hline S5 & 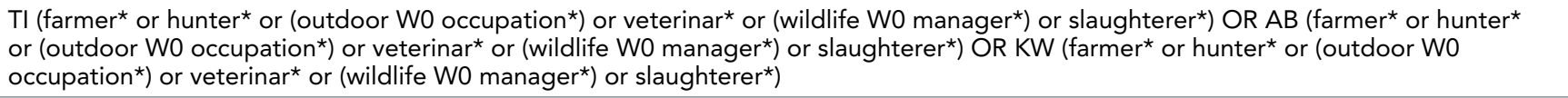 \\
\hline S6 & S4 OR S5 \\
\hline S7 & S3 AND S6 \\
\hline S8 & S7 and LA (english OR french) \\
\hline S9 & S8 and (DT 1995-2018) \\
\hline S10 & S9 NOT PT (editorial or letter or commentary) \\
\hline S11 & $\begin{array}{l}\text { TI (((systematic OR state-of-the-art OR scoping OR literature) W0 (review OR reviews OR overview* OR assessment*)) OR "review* } \\
\text { of reviews" OR meta-analy* OR metaanaly* OR ((systematic OR evidence) N1 assess }{ }^{\star} \text { OR "research evidence" OR synthes?s OR } \\
\left.\text { metasynthe* OR meta-synthe }{ }^{\star}\right) \text { OR SU (((systematic OR state-of-the-art OR scoping OR literature) W0 (review OR reviews OR overview* } \\
\left.\text { OR assessment*)) OR "review* of reviews" OR meta-analy* OR metaanaly* OR ((systematic OR evidence) N1 assess }{ }^{\star}\right) \text { OR "research } \\
\text { evidence" OR synthes?s OR metasynthe* OR meta-synthe*) }\end{array}$ \\
\hline S12 & S10 AND S11 \\
\hline $\mathrm{S} 13$ & S10 NOT S11 \\
\hline
\end{tabular}

reading of the selected publications led to the selection of only those articles that dealt specifically with the zoonoses of interest and that referred to the workplace as a place of acquisition. Studies not involving a work environment (i.e. community acquisition) or that mentioned exposure circumstances that could not have occurred in Québec workplaces were excluded. Reviewing the references listed in the selected publications allowed for the identification of relevant elements in articles published prior to 1995 . Finally, studies for which the descriptions of zoonotic cases did not meet the criteria of the provincial nosological definitions or the diagnostic criteria used in Québec were excluded. The data collected from the selected articles (sectors of economic activity, occupations at risk, risk factors) were recapped in summary analysis grids.

Figure 1 shows the process leading to the selection of information. The research team determined the occupations and sectors of economic activity most at risk for the acquisition of these zoonoses based on the number of articles documenting them. 
Figure 1: Illustration of the process for documentation searches and selection of publications Database search algorithms

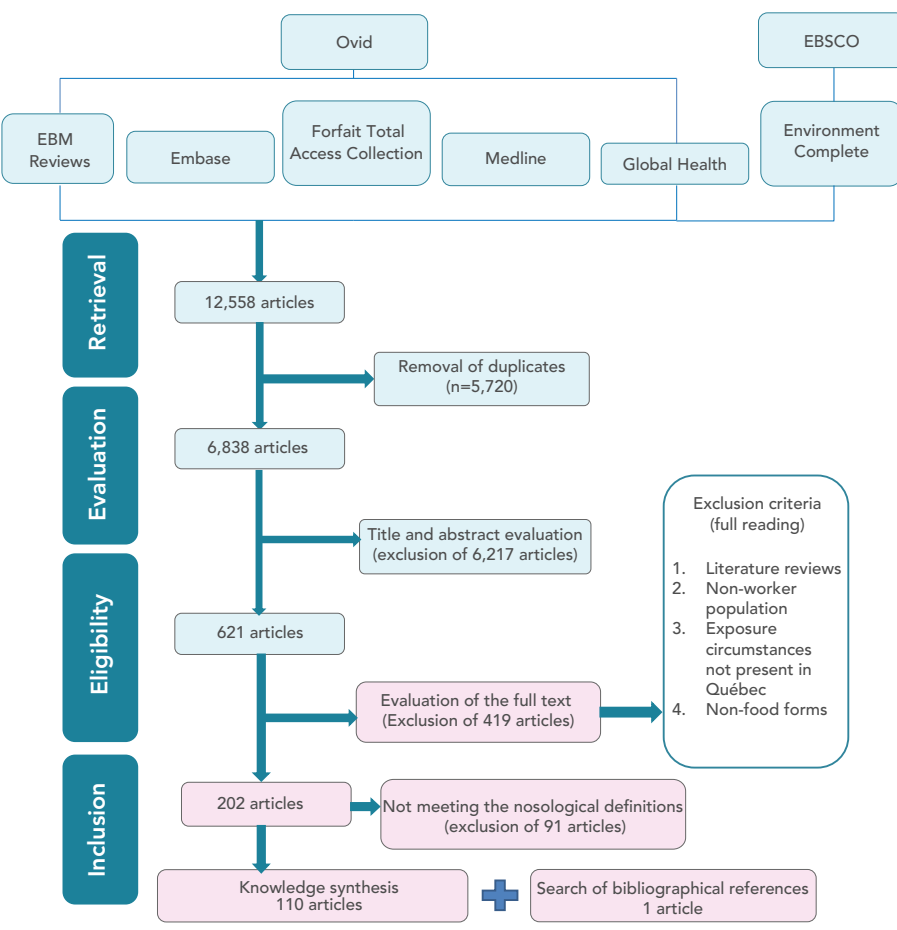

Note: Five databases were queried on the Ovid platform: Embase, Ovid MEDLINE, EvidenceBased Medicine Reviews (EBMR), Forfait Total Access Collection and Global Health; one database was queried on the EBSCO platform: Environment Complete (EC)

Restrictions applied: 1995-2018; English and French; commentaries, editorials, news, opinion letters and Q\&A excluded. No restrictions in terms of geographic scope were applied to initiate the search

\section{Results}

A list of the occupations and sectors of economic activity most at risk for the acquisition of prioritized zoonotic diseases is presented in Table 3. These are classified according to the National Occupational Classification system version 2016 version 1.3 and the 1984 Québec Economic Activity Classification version 1990, respectively. The distribution of selected articles by prioritized zoonosis is available in Table 4

According to the scientific literature evaluated, the most commonly reported zoonoses in workplaces are enteric zoonoses, followed by non-vector-borne non-enteric zoonoses and vector-borne zoonoses. Salmonellosis and cryptosporidiosis are the enteric zoonoses most frequently identified in the literature evaluated. Of vector-borne zoonoses, Lyme disease is the most documented, while very few articles that deal with arboviruses in workers, such as West Nile virus and Eastern equine encephalitis, have been identified. Of non-vector-borne non-enteric zoonoses, most of the scientific articles selected were about $\mathrm{Q}$ fever.

Agriculture, including veterinary services, was the sector in which the most important zoonoses can be contracted. The public administration service sector, which includes national security and defence, was also specifically identified as at risk for the acquisition of the three categories of zoonoses, enteric, vectorborne non-enteric and non-vector-borne non-enteric. The third most frequently mentioned sector were medical and social services, which includes childcare staff, laboratory personnel,

Table 3: Categories of zoonoses, their main reservoir animals in Québec and main sectors of economic activity and occupations identified as at risk for the acquisition of these zoonoses in the scientific literature

\begin{tabular}{|c|c|c|c|}
\hline Zoonoses & Main reservoir animals & Main sectors of economic activity & Occupations and references \\
\hline \multicolumn{4}{|l|}{ Enteric zoonoses } \\
\hline \multirow[t]{2}{*}{ Campylobacteriosisx } & \multirow[t]{2}{*}{ Poultry } & Agriculture & $\begin{array}{l}\text { Farm workers, poultry industry } \\
\text { workers (4-13) }\end{array}$ \\
\hline & & Public administration & Military personnel (14-19) \\
\hline \multirow{3}{*}{ Cryptosporidiosis } & \multirow{3}{*}{ Cattle and other ruminants } & Agriculture & $\begin{array}{l}\text { Veterinary medicine students }(20-27) \text {, } \\
\text { farm workers }(28-33) \text { and agricultural } \\
\text { emergency responders }(34,35)\end{array}$ \\
\hline & & Other business and personal services & $\begin{array}{l}\text { Field trip attendants and summer } \\
\text { camp employees (36-38) }\end{array}$ \\
\hline & & Medical and social services & $\begin{array}{l}\text { Childcare staff (39) and animal } \\
\text { research laboratory personnel (40) }\end{array}$ \\
\hline \multirow{4}{*}{$\begin{array}{l}\text { Verocytotoxigenic } \\
\text { Escherichia coli }\end{array}$} & \multirow{4}{*}{$\begin{array}{l}\text { Cattle, other ruminant or } \\
\text { herbivorous mammals }\end{array}$} & Agriculture & Agricultural workers (41-48) \\
\hline & & Medical and social services & $\begin{array}{l}\text { Childcare staff }(49,50), \text { hospital staff } \\
\text { (nurses) and nursing home staff }(51,52)\end{array}$ \\
\hline & & Teaching and related services & $\begin{array}{l}\text { School-based employees (teachers } \\
\text { and teaching assistants) (53) }\end{array}$ \\
\hline & & Public administration & Military personnel (54) \\
\hline Giardiasis & Cattle, wildlife mammals & Medical and social services & Childcare staff (55-57) \\
\hline Listeriosis & Cattle, sheep, pigs, goats & Agriculture & $\begin{array}{l}\text { Veterinarians }(58,59) \text { and farm workers } \\
(60)\end{array}$ \\
\hline
\end{tabular}


Table 3: Categories of zoonoses, their main reservoir animals in Québec and main sectors of economic activity and occupations identified as at risk for the acquisition of these zoonoses in the scientific literature (continued)

\section{Zoonoses}

Main reservoir animals

Main sectors of economic activity

Occupations and references

Enteric zoonoses

\begin{tabular}{|c|c|c|c|}
\hline \multirow{7}{*}{ Salmonellosis } & \multirow{7}{*}{ Poultry, pigs, cattle } & Agriculture & $\begin{array}{l}\text { Technicians and veterinary medicine } \\
\text { professionals (61-64), farm workers } \\
\text { (65-67), snake farm employees (68) }\end{array}$ \\
\hline & & Medical and social services & $\begin{array}{l}\text { Healthcare workers (69-71), nursing } \\
\text { home staff }(72) \text { and childcare staff } \\
(73,74)\end{array}$ \\
\hline & & Public administration & Military $(75,76)$ \\
\hline & & Miscellaneous manufacturing industries & Pet industry staff (77) \\
\hline & & Food and beverage industry & Workers exposed to raw meat (78) \\
\hline & & Building and public works & Construction workers (79) \\
\hline & & Other business and personal services & Restaurant employees (80) \\
\hline \multicolumn{4}{|c|}{ Vector-borne non-enteric zoonoses } \\
\hline $\begin{array}{l}\text { Eastern equine } \\
\text { encephalitis }\end{array}$ & Wild birds (e.g. passerines) & Agriculture & Veterinary technicians (81) \\
\hline \multirow{3}{*}{ Lyme disease } & \multirow{3}{*}{$\begin{array}{l}\text { White-footed mouse } \\
\text { (Peromyscus leucopus) }\end{array}$} & Agriculture & Farm workers (82-85) \\
\hline & & Forestry and sawmills & Forestry workers (85) \\
\hline & & Public administration & Military personnel (86-89) \\
\hline \multirow{3}{*}{ West Nile virus } & \multirow{3}{*}{$\begin{array}{l}\text { Avian (especially } \\
\text { passerines) }\end{array}$} & Medical and social services & Laboratory personnel (90) \\
\hline & & Other business and personal services & Animal control officers (91) \\
\hline & & Agriculture & Veterinary medicine students (92) \\
\hline \multicolumn{4}{|c|}{ Non-vector-borne non-enteric zoonoses } \\
\hline $\begin{array}{l}\text { Foodborne botulism in } \\
\text { Nunavik }\end{array}$ & Seals & No information & No information \\
\hline \multirow{5}{*}{ Q fever } & \multirow{5}{*}{ Domestic ruminants } & Public administration & Military personnel (93-97) \\
\hline & & Agriculture & Farm workers $(98,99)$ \\
\hline & & Food and beverage industry & Slaughterhouse workers (100) \\
\hline & & Chemical industry & Cosmetics industry workers $(101,102)$ \\
\hline & & Transportation and warehousing & Drivers (103) \\
\hline Avian and swine influenza & Avian (wild birds), pigs & Agriculture & $\begin{array}{l}\text { Commercial poultry farm workers } \\
(104)\end{array}$ \\
\hline \multirow{3}{*}{ Rabies } & \multirow{3}{*}{$\begin{array}{l}\text { Arctic foxes, raccoons, } \\
\text { bats }\end{array}$} & Public administration & Military personnel $(105,106)$ \\
\hline & & Agriculture & Veterinary services (107) \\
\hline & & Other business and personal services & Employees in contact with bats (108) \\
\hline \multirow{4}{*}{$\begin{array}{l}\text { Hantavirus pulmonary } \\
\text { syndrome }\end{array}$} & \multirow{4}{*}{$\begin{array}{l}\text { Deer mouse } \\
\text { (Peromyscus maniculatus) }\end{array}$} & Agriculture & Farm workers (109-111) \\
\hline & & Forestry and sawmills & Forest workers (109) \\
\hline & & Public administration & Military personnel (112) \\
\hline & & Other business and personal services & $\begin{array}{l}\text { Trapping and handling of rodents for } \\
\text { ecological studies (113) } \\
\text { Communications, power transmission } \\
\text { and other utilities (114) }\end{array}$ \\
\hline
\end{tabular}




\section{Table 4: Number of articles retained by prioritized} zoonosis

\begin{tabular}{|l|r|}
\hline \multicolumn{1}{|c|}{ Prioritized zoonoses } & $\begin{array}{l}\text { Number of scientific publications } \\
\text { for which case descriptions meet } \\
\text { the criteria of the nosological } \\
\text { definitions and diagnostic criteria }\end{array}$ \\
\hline $\begin{array}{l}\text { Foodborne botulism in } \\
\text { Nunavik }\end{array}$ & 0 \\
\hline Campylobacteriosis & 16 \\
\hline Cryptosporidiosis & 21 \\
\hline Eastern equine encephalitis & 1 \\
\hline $\begin{array}{l}\text { Verocytotoxigenic } \\
\text { Escherichia coli }\end{array}$ & 14 \\
\hline Q fever & 11 \\
\hline Giardiasis & 3 \\
\hline $\begin{array}{l}\text { Hantavirus pulmonary } \\
\text { syndrome }\end{array}$ & 6 \\
\hline Avian and swine influenza & 1 \\
\hline Listeriosis & 3 \\
\hline Lyme disease & 8 \\
\hline Rabies & 4 \\
\hline Salmonellosis & 20 \\
\hline West Nile virus & 3 \\
\hline Two zoonoses or more & $22^{\mathrm{a}}$ \\
\hline Total & 111 \\
\hline of the zoonoses concerned, i.e. campylobacteriosis, cryptosporidiosis and salmonellosis, but are \\
counted only once & 14 \\
\hline
\end{tabular}

hospital staff, long-term care centre staff and nursing home staff, among others. This sector was identified as at greater risk for contracting enteric zoonoses such as cryptosporidiosis, verocytotoxigenic E. coli, giardiasis and salmonellosis and one vector-borne zoonosis (accidental transmission of West Nile virus among laboratory personnel).

\section{Discussion}

The objective of this study was to describe the occupations and sectors at risk for the acquisition of zoonoses of public health importance in Québec. Different occupations are at varying risk of contracting one of the 14 zoonoses prioritized as important to public health by Québec's Multi-Party Observatory on Zoonoses and Adaptation to Climate. Farm workers and veterinarians, as well as military personnel and medical and social services personnel are among the workers most frequently documented as at risk.

There is shortage of literature documenting at-risk occupations that would guide preventive occupational health measures. Two published studies allowed us to compare certain observations.
A systematic review of the scientific literature (1999-2008, no geographic restriction) by Haagsma et al. (115) examined occupational injuries attributable to infectious diseases. The second study presented the extent of occupational injuries attributable to infectious diseases reported in the United States between 2006 and 2015 (116). Su et al. (116) conducted a review of 67 peer-reviewed scientific publications (published between 2006 and 2016) by following the methodology used by Haagsma et al. (115) and supplemented this research by evaluating 66 case reports of workplace-acquired infectious diseases from the Center for Disease of the National Institute for Occupational Safety and Health.

In this study, the military was identified as being at risk for the acquisition of three categories of zoonotic diseases (enteric and vector-borne non-enteric and non-vector-borne non-enteric), especially during missions abroad. The military was not widely discussed by Su et al. (116) or Haagsma et al. (115), with the exception of the risk for leishmaniasis, a parasitic infection that is not present in Canada. Several of the studies that focused on the military were published after 2008, i.e. after the time period covered by Haagsma et al. (115) and Su et al. (116), which explains some of the difference in observations between those studies and our research. This study identified several risk factors for the acquisition of zoonoses by military personnel: being based in endemic areas; participating in training camps in or near wooded areas (Lyme disease) $(87,88)$; living in abandoned structures or barns in which animals have reproduced; and working in deployment sites where dust becomes air-borne because of air turbulence caused by helicopters ( $\mathrm{Q}$ fever) $(93,94,96,97)$.

Similar to Su et al.'s (116) observations, it was found that enteric zoonoses of bacterial etiology are the workplace zoonoses most frequently found from among the zoonoses of importance. This study also showed that three sectors are particularly affected by zoonoses of importance: agriculture, including veterinary services; public administration services including defence; and medical and social services. This was also observed by Haagsma et al. (115) and Su et al. (116), who reported that healthcare workers and those in contact with animals are most at risk of being infected by a variety of zoonotic pathogens. Healthcare workers are predominantly exposed to pathogens through human-to-human contact (115). Infection occurs accidentally through wounds or needlesticks, and also through direct skin contact or indirectly via oral-fecal contact, often related to hand hygiene. Su et al. (116) explain that workers in contact with animals, particularly livestock and/or poultry, are at risk of contracting zoonoses. Haagsma et al. (115) identified farmers, slaughterhouse workers, animal care workers, veterinarians, hunters and gardeners as those at risk for the acquisition of zoonoses following contact with animals. All of these occupations were identified in our study as being at risk. 


\section{Strengths and limitations}

The main limitation of this study hinges on the inclusion and exclusion criteria used in the search strategy. Selecting only those published studies where the description of zoonotic cases meets the nosological definitions or diagnostic criteria may have resulted in the exclusion of studies presenting asymptomatic infection cases diagnosed in the laboratory. Despite this limitation, the conclusions of our review are similar to those reported in two other literature reviews $(115,116)$. However, the results of this study reflect a publication bias. To illustrate, it is not surprising that more articles on Lyme disease were retrieved than on the two other vector-borne zoonotic diseases under study given the amount of recent research on this disease. This therefore calls for a cautious interpretation of the importance of the documentation on each of the zoonoses.

\section{Conclusion}

This study has painted a portrait of the occupations and sectors most at risk for the acquisition of prioritized zoonoses in Québec. Agriculture (including veterinary workers), public administration personnel (in particular the military) and medical and social services were identified as the sectors most affected by the prioritized zoonoses. Military personnel have also been identified as at risk of contracting the three categories of zoonoses, with several risk factors were identified for the acquisition of zoonoses in the military.

Overall, risks of acquiring zoonotic diseases in the workplace have not been widely studied. Future studies would include consulting representatives at various workplaces and zoonosis experts to build on observations. It would also be valuable to identify the measures put in place to protect the workforce from zoonoses. This would ultimately help to identify any gaps and better guide public health adaptation efforts in the context of climate change.

\section{Authors' statement}

AAP - Concept, writing-original draft, revising the writing, critical review

LMD - Concept, writing-original draft, revising the writing, critical review

$\mathrm{SB}$ - Revising the writing and critical review

GG - Revising the writing and critical review

AIC - Revising the writing and critical review

MPS - Revising the writing and critical review

AS - Revising the writing and critical review

JS - Revising the writing and critical review

$\mathrm{KT}$ - Revising the writing and critical review

FT - Revising the writing and critical review

\section{Competing interests}

None to declare.

\section{Acknowledgements}

The authors would like to thank Ms. M Lacourse from the Scientific Promotion, Communications and Organizational Performance Department of the Institut national de santé publique du Québec for her support in defining the bibliographic search strategy as well as the members of the follow up Committee for their important contribution.

\section{Funding}

This publication was produced under the financial participation obtained under the 2013-2020 Action Plan on Climate Change of the Government of Québec.

The content and view expressed in this article are those of the authors and do not necessarily reflect those of the Government of Canada.

\section{References}

1. Germain G, Simon A, Arsenault J, Baron G, Bouchard C, Chaumont D, El Allaki F, Kimpton A, Lévesque B, Massé A, Mercier M, Ogden NH, Picard I, Ravel A, Rocheleau JP, Soto J. Quebec's Multi-Party Observatory on Zoonoses and Adaptation to Climate Change. Can Commun Dis Rep 2019;45(5):143-8. DOI PubMed

2. Institut national de santé publique du Québec et Université de Montréal. Observatoire multi-partite québécois sur les zoonoses et l'adaptation aux changements climatiques. Bouchard C, Lowe AM, Simon A. Portrait des zoonoses priorisées par l'Observatoire multipartite québécois sur les zoonoses et l'adaptation aux changements climatiques en 2015. Montréal (QC) : INSPQ, 2017. https://www. inspq.qc.ca/sites/default/files/publications/2290_portrait_ zoonoses_priorisees_2015.pdf

3. Institut national de santé publique du Québec et Université de Montréal. Observatoire multi-partite québécois sur les zoonoses et l'adaptation aux changements climatiques. Simon A, Aenishaenslin C, Hongoh V, Lowe, AM. Priorisation des zoonoses au Québec dans un contexte d'adaptation aux changements climatiques à l'aide d'un outil d'aide à la décision multicritère. Montréal (QC) : INSPQ, 2018. https:// www.inspq.qc.ca/sites/default/files/publications/2432 priorisation_zoonoses_quebec_outil_aide_decision_ multicritere.pdf

4. Campylobacter jejuni Infections Associated With Sheep Castration in Wyoming, 2011. MMWR 2011;60(48):1654.

5. de Perio MA, Niemeier RT, Levine SJ, Gruszynski K, Gibbins JD. Campylobacter infection in poultry-processing workers, Virginia, USA, 2008-2011. Emerg Infect Dis 2013;19(2):286-8. DOI PubMed 
6. Ellis A, Irwin R, Hockin J, Borczyk A, Woodward D, Johnson W. Outbreak of Campylobacter infection among farm workers: an occupational hazard. Canada communicable disease report 1995;21(17):153-6. http:// publications.gc.ca/collections/Collection/H12-21-21-17E.pdf

7. Ellström P, Hansson I, Söderström C, Engvall EO, Rautelin H. A prospective follow-up study on transmission of Campylobacter from poultry to abattoir workers. Foodborne Pathog Dis 2014 Sep;11(9):684-8. DOI PubMed

8. Ganeshram KN, Ross A, Cowell RP, Cefai C, Woodward MJ. Recurring febrile illness in a slaughterhouse worker. Postgrad Med J 2000 Dec;76(902):790-1. DOl PubMed

9. Gilpin BJ, Scholes P, Robson B, Savill MG. The transmission of thermotolerant Campylobacter spp. to people living or working on dairy farms in New Zealand. Zoonoses Public Health 2008 Sep;55(7):352-60. DOI PubMed

10. Heryford AG, Seys SA. Outbreak of occupational campylobacteriosis associated with a pheasant farm. J Agric Saf Health 2004 May;10(2):127-32. DOI PubMed

11. Iraola G, Betancor L, Calleros L, Gadea P, Algorta G, Galeano S, et al. A rural worker infected with a bovine-prevalent genotype of Campylobacter fetus subsp. fetus supports zoonotic transmission and inconsistency of MLST and whole-genome typing. Eur J Clin Micro-biol Infect Dis 2015;34(8):1593-6. DOl PubMed

12. Padungtod $P$, Kaneene JB. Campylobacter in food animals and humans in northern Thailand. J Food Prot 2005;68(12):2519-26. DOI PubMed

13. Wilson IG. Airborne Campylobacter infection in a poultry worker: case report and review of the literature. Commun Dis Public Health 2004;7(4):349-53. PubMed

14. Armed Forces Health Surveillance Center (AFHSC). Incidence of Campylobacter infections among service members of the active and reserve components of the U.S. Armed Forces and among other beneficiaries of the Military Health System, 2000-2013. MSMR 2014;21(12):11-6. PubMed

15. Beecham HJ 3rd, Lebron Cl, Echeverria P. Short report: impact of traveler's diarrhea on United States troops deployed to Thailand. Am J Trop Med Hyg 1997;57(6):699-701. DOI PubMed

16. Hennessy EP. An outbreak of campylobacteriosis amongst directing staff and students at the Infantry Training Centre, Brecon, Wales, March 2004. J R Army Med Corps 2004;150(3):175-8. DOl PubMed

17. O'Donnell FL, Stahlman S, Oh GT. Incidence of Campylobacter intestinal infections, active component, U.S. Armed Forces, 2007-2016. MSMR 2017;24(6):2-5. PubMed
18. Sanders JW, Isenbarger DW, Walz SE, Pang LW, Scott DA, Tamminga C, Oyofo BA, Hewitson WC, Sanchez JL, Pitarangsi C, Echeverria P, Tribble DR. An observational clinic-based study of diarrheal illness in deployed United States military personnel in Thailand: presentation and outcome of Campylobacter infection. Am J Trop Med Hyg 2002;67(5):533-8. DOI PubMed

19. Tribble DR, Baqar S, Pang LW, Mason C, Houng HS, Pitarangsi C, Lebron C, Armstrong A, Sethabutr O, Sanders JW. Diagnostic approach to acute diarrheal illness in a military population on training exercises in Thailand, a region of campylobacter hyperendemicity. J Clin Microbiol 2008;46(4):1418-25. DOI PubMed

20. Benschop J, Booker CM, Shadbolt T, Weston JF. A Retrospective Cohort Study of an Outbreak of Cryptosporidiosis among Veterinary Students. Veterinary sciences. 2017;4(2). http://ovidsp.ovid.com/ovidweb.cgi?T=J $S \& P A G E=$ reference \&D $=$ prem \&NEWS $=N \& A N=29056688$

21. Drinkard LN, Halbritter A, Nguyen GT, Sertich PL, King $M$, Bowman S, Huxta R, Guagenti M. Notes from the Field: Outbreak of Cryptosporidiosis Among Veterinary Medicine Students--Philadelphia, Pennsylvania, February 2015. MMWR Morb Mortal Wkly Rep 2015;64(28):773. DOI PubMed

22. Gait R, Soutar RH, Hanson M, Fraser C, Chalmers R. Outbreak of cryptosporidiosis among veterinary students. Vet Rec 2008;162(26):843-5. DOI PubMed

23. Galuppi R, Piva S, Castagnetti C, Sarli G, lacono E, Fioravanti ML, Caffara M. Cryptosporidium parvum: from foal to veterinary students. Vet Parasitol 2016;219:53-6. DOl PubMed

24. Grinberg A, Pomroy WE, Squires RA, Scuffham A, Pita A, Kwan E. Retrospective cohort study of an outbreak of cryptosporidiosis caused by a rare Cryptosporidium parvum subgenotype. Epidemiol Infect 2011;139(10):1542-50. DOl PubMed

25. Kinross P, Beser J, Troell K, Axén C, Björkman C, Lebbad M, Winiecka-Krusnell J, Lindh J, Löfdahl M. Cryptosporidium parvum infections in a cohort of veterinary students in Sweden. Epidemiol Infect 2015;143(13):2748-56. DOI PubMed

26. Konkle DM, Nelson KM, Lunn DP. Nosocomial transmission of Cryptosporidium in a veterinary hospital. J Vet Intern Med 1997;11(6):340-3. DOl PubMed

27. Preiser G, Preiser L, Madeo L. An outbreak of cryptosporidiosis among veterinary science students who work with calves. J Am Coll Health 2003;51(5):213-5. DOI PubMed

28. Lassen B, Ståhl M, Enemark HL. Cryptosporidiosis - an occupational risk and a disregarded disease in Estonia. Acta Vet Scand 2014;56:36. DOI PubMed

29. El-Sherbini GT, Mohammad KA. Zoonotic cryptosporidiosis in man and animal in farms, Giza Governorate, Egypt. J Egypt Soc Parasitol 2006;36(2 Suppl):49-58. PubMed 
30. Izadi M, Jonaidi-Jafari N, Saburi A, Eyni H, Rezaiemanesh MR, Ranjbar R. Cryptosporidiosis in Iranian Farm Workers and Their Household Members: A Hypothesis about Possible Zoonotic Transmission. J Trop Med 2014;2014:405875. DOI PubMed

31. Mahdi NK, Ali NH. Cryptosporidiosis among animal handlers and their livestock in Basrah, Iraq. East Afr Med J 2002;79(10):550-3. DOI PubMed

32. Ng JS, Eastwood K, Walker B, Durrheim DN, Massey PD, Porigneaux P, Kemp R, McKin-non B, Laurie K, Miller D, Bramley E, Ryan U. Evidence of Cryptosporidium transmission between cattle and humans in northern New South Wales. Exp Parasitol 2012;130(4):437-41. DOI PubMed

33. Siwila J, Phiri IG, Vercruysse J, Goma F, Gabriel S, Claerebout E, Geurden T. Asymptomatic cryptosporidiosis in Zambian dairy farm workers and their household members. Trans R Soc Trop Med Hyg 2007;101(7):733-4. DOI PubMed

34. Webb LM, Tubach SA, Hunt DC; Centers for Disease Control and Prevention (CDC). Outbreak of cryptosporidiosis among responders to a rollover of a truck carrying calves - Kansas, April 2013. MMWR Morb Mortal Wkly Rep 2014;63(50):1185-8. PubMed

35. Centers for Disease Control and Prevention (CDC). Outbreak of cryptosporidiosis associated with a firefighting response Indiana and Michigan, June 2011. MMWR Morb Mortal Wkly Rep 2012;61(9):153-6. PubMed

36. Centers for Disease Control and Prevention (CDC). Cryptosporidiosis outbreak at a summer camp-North Carolina, 2009. MMWR Morb Mortal Wkly Rep 2011;60(27):918-22. PubMed

37. Evans MR, Gardner D. Cryptosporidiosis outbreak associated with an educational farm holiday. CDR Rev 1996 Mar;6(3):R50-1. PubMed

38. Hoek MR, Oliver I, Barlow M, Heard L, Chalmers R, Paynter S. Outbreak of Cryptosporidium parvum among children after a school excursion to an adventure farm, south west England. J Water Health 2008;6(3):333-8. DOI PubMed

39. Cordell RL, Thor PM, Addiss DG, Theurer J, Lichterman R, Ziliak SR, Juranek DD, Davis JP. Impact of a massive waterborne cryptosporidiosis outbreak on child care facilities in metropolitan Milwaukee, Wisconsin. Pediatr Infect Dis J 1997;16(7):639-44. DOI PubMed

40. Hancock-Allen J, Alden NB, Cronquist AB. Cryptosporidiosis outbreak at an academic animal research laboratory-Colorado, 2014. Am J Ind Med 2017;60(2):208-14. DOI PubMed

41. Chalmers RM, Salmon RL, Willshaw GA, Cheasty T, Looker N, Davies I, Wray C. Vero-cytotoxin-producing Escherichia coli 0157 in a farmer handling horses. Lancet 1997;349(9068):1816. DOI PubMed
42. Hong S, Oh KH, Cho SH, Kim JC, Park MS, Lim HS, Lee BK. Asymptomatic healthy slaughterhouse workers in South Korea carrying Shiga toxin-producing Escherichia coli. FEMS Immunol Med Microbiol 2009;56(1):41-7. DOI PubMed

43. Hong S, Song SE, Oh KH, Kim SH, Yoo SJ, Lim HS, Park MS. Prevalence of Farm and Slaughterhouse Workers Carrying Shiga Toxin-Producing Escherichia coli in Korea. Osong Public Health Res Perspect 2011;2(3):198-201. DOI PubMed

44. Park JH, Lim HS, Lee K, Hong S, Park MS. Prevalence of Shiga toxin-encoding genes and risk factors among dairy farmers in Gyeonggi Province, Korea. Scand J Infect Dis 2011;43(4):275-9. DOl PubMed

45. Rehman MU, Mohd R, Maninder S, Nitasha S, Reshi IA. Isolation, characterization and association of Shiga toxin-producing Escherichia coli from bovines and their handlers in Jammu, India. J Pure Appl Microbiol 2014;8(3):2353-8. https://microbiologyjournal.org/ isolation-characterization-and-association-of-shig a-toxin-producing-escherichia-coli-from-bovines-an d-their-handlers-in-jammu-india/

46. Silvestro L, Caputo M, Blancato S, Decastelli L, Fioravanti A, Tozzoli R, Morabito S, Caprioli A. Asymptomatic carriage of verocytotoxin-producing Escherichia coli 0157 in farm workers in Northern Italy. Epidemiol Infect 2004;132(5):915-9. DOI PubMed

47. Stephan R, Untermann F. Virulence factors and phenotypical traits of verotoxin-producing Escherichia coli strains isolated from asymptomatic human carriers. J Clin Microbiol 1999;37(5):1570-2. DOI PubMed

48. Durso LM, Reynolds K, Bauer N Jr, Keen JE. Shiga-toxigenic Escherichia coli O157:H7 infections among livestock exhibitors and visitors at a Texas County Fair. Vector Borne Zoonotic Dis 2005;5(2):193-201. DOI PubMed

49. Brown JA, Hite DS, Gillim-Ross LA, Maguire HF, Bennett JK, Patterson JJ, Comstock NA, Watkins AK, Ghosh TS, Vogt RL. Outbreak of shiga toxin-producing Escherichia coli serotype O26: $\mathrm{H} 11$ infection at a child care center in Colorado. Pediatr Infect Dis J 2012;31(4):379-83. DOI PubMed

50. O'Donnell JM, Thornton L, McNamara EB, Prendergast T, Igoe D, Cosgrove C. Outbreak of Vero cytotoxin-producing Escherichia coli $\mathrm{O} 157$ in a child day care facility. Commun Dis Public Health 2002;5(1):54-8. PubMed

51. Afza M, Hawker J, Thurston H, Gunn K, Orendi J. An outbreak of Escherichia coli $\mathrm{O} 157$ gastroenteritis in a care home for the elderly. Epidemiol Infect 2006;134(6):1276-81. DOI PubMed

52. Weightman NC, Kirby PJ. Nosocomial Escherichia coli $O 157$ infection. J Hosp Infect 2000;44(2):107-11. DOI PubMed

53. Bayliss L, Carr R, Edeghere O, Knapper E, Nye K, Harvey G, Adak G, Duggal H. School outbreak of Escherichia coli O157 with high levels of transmission, Staffordshire, England, February 2012. J Public Health (Oxf) 2016;38(3):e247-53. DOI PubMed 
54. Porter CK, Riddle MS, Tribble DR, Putnam SD, Rockabrand DM, Frenck RW, Rozmajzl P, Kilbane E, Fox A, Ruck R, Lim M, Johnston J, Murphy E, Sanders JW. The epidemiology of travelers' diarrhea in Incirlik, Turkey: a region with a predominance of heat-stabile toxin producing enterotoxigenic Escherichia coli. Diagn Microbiol Infect Dis 2010;66(3):241-7. DOI PubMed

55. Ang LH. Outbreak of giardiasis in a daycare nursery. Commun Dis Public Health 2000;3(3):212-3. PubMed

56. Guimarães S, Sogayar MI. Occurrence of Giardia lamblia in children of municipal day-care centers from Botucatu, São Paulo State, Brazil. Rev Inst Med Trop São Paulo 1995;37(6):501-6. DOI PubMed

57. Linnane E, Roberts R, Looker N. Nappies and transmission of Giardia lamblia between children. Lancet 2001;358(9280):507. DOl PubMed

58. Laureyns J, Moyaert H, Werbrouck H, Catry B, de Kruif A, Pasmans F. Pustular dermatitis by Listeria monocytogenes after the assisted delivery of a dead calf. Vlaams Diergeneeskd Tijdschr 2008;77(1):29-34. https://vdt.ugent. be/sites/default/files/art77105.pdf

59. Regan EJ, Harrison GA, Butler S, McLauchlin J, Thomas M, Mitchell S. Primary cutaneous listeriosis in a veterinarian. Vet Rec 2005;157(7):207. DOI PubMed

60. Gilchrist M. Cutaneous Listeria infection. British journal of hospital medicine (London, England : 2005). 2009;70(11):659.

61. Lazarus R, Waghorn D, Nash C. Cutaneous Salmonella infection. Scand J Infect Dis 2007;39(3):257-8. DOI PubMed

62. Bemis DA, Craig LE, Dunn JR. Salmonella transmission through splash exposure during a bovine necropsy. Foodborne Pathog Dis 2007;4(3):387-90. DOI PubMed

63. Anonymous. From the Centers for Disease Control and Prevention. Outbreaks of multidrug-resistant Salmonella typhimurium associated with veterinary facilities-Idaho, Minnesota, and Washington, 1999. JAMA 2001;286(16):1965-6. PubMed

64. Cherry B, Burns A, Johnson GS, Pfeiffer H, Dumas N, Barrett D, McDonough PL, Eidson M. Salmonella Typhimurium outbreak associated with veterinary clinic. Emerg Infect Dis 2004;10(12):2249-51. DOI PubMed

65. Padungtod P, Kaneene JB. Salmonella in food animals and humans in northern Thailand. Int J Food Microbiol 2006;108(3):346-54. DOl PubMed

66. Gong J, Wang $C$, Shi $S$, Bao H, Zhu C, Kelly P, Zhuang L, Lu G, Dou X, Wang R, Xu B, Zou J. Highly Drug-Resistant Salmonella enterica Serovar Indiana Clinical Isolates Recovered from Broilers and Poultry Workers with Diarrhea in China. Antimicrob Agents Chemother 2016;60(3):1943-7. DOI PubMed
67. Baker MG, Thornley CN, Lopez LD, Garrett NK, Nicol CM. A recurring salmonellosis epidemic in New Zealand linked to contact with sheep. Epidemiol Infect 2007;135(1):76-83. DOI PubMed

68. Prapasarakul N, Pulsrikarn C, Vasaruchapong T, Lekcharoen P, Chanchaithong P, Lugsomya K, Keschumras N, Thanomsuksinchai N, Tanchiangsai K, Tummaruk P. Salmonella serovar distribution in cobras (Naja kaouthia), snake-food species, and farm workers at Queen Saovabha Snake Park, Thailand. Journal of veterinary diagnostic investigation Inc. 2012;24(2):288-94. DOI

69. Alexander DC, Fitzgerald SF, DePaulo R, Kitzul R, Daku D, Levett PN, Cameron AD. Laboratory-Acquired Infection with Salmonella enterica Serovar Typhimurium Exposed by Whole-Genome Sequencing. J Clin Microbiol 2016;54(1):190-3. DOI PubMed

70. Centers for Disease Control and Prevention (CDC). Occupationally acquired Salmonella | 4,12:i:1,2 infection in a phlebotomist--Minnesota, January 2013. MMWR Morb Mortal Wkly Rep 2013;62(25):525. PubMed

71. Centers for Disease Control and Prevention (CDC). Salmonella serotype enteritidis infections among workers producing poultry vaccine--Maine, November-December 2006. MMWR Morb Mortal Wkly Rep 2007;56(34):877-9. PubMed

72. Standaert SM, Hutcheson RH, Schaffner W. Nosocomial transmission of Salmonella gastroenteritis to laundry workers in a nursing home. Infect Control Hosp Epidemiol 1994;15(1):22-6. DOI PubMed

73. Newcomb S, Broadhurst L, Kissane K. Salmonella outbreak in an American child development center in Germany. Mil Med 1997;162(12):783-7. DOl PubMed

74. Dontsenko I, Võzelevskaja N, Põld A, Kerbo N, Kutsar K. Outbreak of salmonellosis in a kindergarten in Estonia, May 2008. Euro Surveill 2008;13(24):18900. PubMed

75. Clark LL, Daniele DO, O'Donnell FL. Incidence of Salmonella infections among service members of the active and reserve components of the U.S. Armed Forces and among other beneficiaries of the Military Health System, 2000-2013. MSMR 2015;22(1):11-5. PubMed

76. Williams VF, Stahlman S, Oh GT. Incidence of nontyphoidal Salmonella intestinal infections, active component, U.S. Armed Forces, 2007-2016. MSMR 2017;24(6):6-10. PubMed

77. Bartholomew ML, Heffernan RT, Wright JG, Klos RF, Monson T, Khan S, Trees E, Sabol A, Willems RA, Flynn R, Deasy MP, Jones B, Davis JP. Multistate outbreak of Salmonella enterica serotype enteritidis infection associated with pet guinea pigs. Vector Borne Zoonotic Dis 2014;14(6):414-21. DOI PubMed 
78. Doorduyn $Y$, Van Den Brandhof WE, Van Duynhoven YT, Wannet WJ, Van Pelt W. Risk factors for Salmonella Enteritidis and Typhimurium (DT104 and non-DT104) infections in The Netherlands: predominant roles for raw eggs in Enteritidis and sandboxes in Typhimurium infections. Epidemiol Infect 2006;134(3):617-26. DOI PubMed

79. Faustini A, Sangalli M, Fantasia M, Manganello R, Mattaccini E, Trippanera R, Spera D, La Rosa U, Topi MT, Forastiere F, Perucci CA. An outbreak of Salmonella hadar associated with food consumption at a building site canteen. Eur J Epidemiol 1998;14(1):99-106. DOI PubMed

80. Evans MR, Hutchings PG, Ribeiro CD, Westmoreland D. A hospital outbreak of salmonella food poisoning due to inadequate deep-fat frying. Epidemiol Infect 1996;116(2):155-60. DOI PubMed

81. Min Z, Gnann JW Jr. Mosquito bites and eastern equine encephalitis. QJM International Journal of Medicine. 2014;107(5):397-8. DOI PubMed

82. Stawicki T. Analysis of the variability of registered cases of Lyme disease among workers of private agriculture in West Pomeranian Voivodship. Folia Pomeranae Universitatis Technologiae Stetinensis, Agricultura, Alimentaria, Piscaria et Zootechnica. 2017;334(42/2):175-85. http://foliaaapz.zut. edu.pl/pdf/files/magazines/1/69/936.pdf

83. Zając V, Pinkas J, Wójcik-Fatla A, Dutkiewicz J, Owoc A, Bojar I. Prevalence of serological response to Borrelia burgdorferi in farmers from eastern and central Poland. Eur J Clin Microbiol Infect Dis 2017;36(3):437-46. DOI PubMed

84. Szeszenia-Dąbrowska N, Świątkowska B, Wilczńska U. Occupational diseases among farmers in Poland. Med $\mathrm{Pr}$ 2016;67(2):163-71. DOI PubMed

85. Bilski B. Occurrence of cases of borreliosis certified as an occupational disease in the province of Wielkopolska (Poland). Ann Agric Environ Med 2009;16(2):211-7. PubMed

86. Anna MM, Escobar JD, Chapman AS. Reported vectorborne and zoonotic diseases, U.S. Air Force, 2000-2011. MSMR 2012;19(10):11-2. PubMed

87. Hurt L, Dorsey KA. The geographic distribution of incident Lyme disease among active component service members stationed in the continental United States, 2004-2013. MSMR 2014;21(5):13-5. PubMed

88. Rossi C, Stromdahl EY, Rohrbeck P, Olsen C, DeFraites RF. Characterizing the relationship between tick bites and Lyme disease in active component U.S. Armed Forces in the eastern United States. MSMR 2015;22(3):2-10. PubMed

89. Armed Forces Health Surveillance Center (AFHSC). Surveillance snapshot: lyme disease among beneficiaries of the Military Health System, 2001-2012. MSMR 2013;20(8):23. PubMed

90. Centers for Disease Control and Prevention (CDC). Laboratory-acquired West Nile virus infections-United States, 2002. MMWR Morb Mortal Wkly Rep 2002;51(50):1133-5. PubMed
91. Fonseca K, Prince GD, Bratvold J, Fox JD, Pybus M, Preksaitis JK, Tilley P. West Nile virus infection and conjunctival exposure. Emerg Infect Dis 2005;11(10):1648-9. DOI PubMed

92. Venter M, Steyl J, Human S, Weyer J, Zaayman D, Blumberg L, Leman PA, Paweska J, Swanepoel R. Transmission of West Nile virus during horse autopsy. Emerg Infect Dis 2010;16(3):573-5. DOI PubMed

93. Anderson AD, Baker TR, Littrell AC, Mott RL, Niebuhr DW, Smoak BL. Seroepidemiologic survey for Coxiella burnetii among hospitalized US troops deployed to Iraq. Zoonoses Public Health 2011;58(4):276-83. DOI PubMed

94. Faix DJ, Harrison DJ, Riddle MS, Vaughn AF, Yingst SL, Earhart K, Thibault G. Outbreak of $Q$ fever among US military in western Iraq, June-July 2005. Clin Infect Dis 2008;46(7):e65-8. DOl PubMed

95. Hartzell JD, Peng SW, Wood-Morris RN, Sarmiento DM, Collen JF, Robben PM, Moran KA. Atypical Q fever in US soldiers. Emerg Infect Dis 2007;13(8):1247-9. DOI PubMed

96. Royal J, Riddle MS, Mohareb E, Monteville MR, Porter CK, Faix DJ. Seroepidemiologic survey for Coxiella burnetii among US military personnel deployed to Southwest and Central Asia in 2005. Am J Trop Med Hyg 2013;89(5):991-5. DOI PubMed

97. White B, Brooks T, Seaton RA. Q fever in military and paramilitary personnel in conflict zones: case report and review. Travel Med Infect Dis 2013;11(2):134-7. DOI PubMed

98. Towey A, Petitti C. OSHA Compliance Issues. J Occup Environ Hyg 2009;6(10):63-5. DOI PubMed

99. Hatchette T, Hudson R, Schlech W, Campbell N, Hatchette J, Ratnam S, Marrie T. Caprine-associated $Q$ fever in Newfoundland. Canada Communicable Disease Report. 2000;26(3):17-9. http://publications.gc.ca/collections/ Collection/H12-21-26-3.pdf

100.Aw TC, Ratti N. Occupational infection in an offal porter: a case of $\mathrm{Q}$ fever. Occup Med (Lond) $1997 ; 47(7): 432-4$. DOl PubMed

101. Wade AJ, Cheng AC, Athan E, Molloy JL, Harris OC, Stenos J, Hughes AJ. Q fever outbreak at a cosmetics supply factory. Clin Infect Dis 2006;42(7):e50-2. DOI PubMed

102. Wade AJ, Walker T, Athan E, Hughes AJ. Spontaneous splenic rupture: a rare complication of $Q$ fever in Australia. Med J Aust 2006;184(7):364. DOI PubMed

103. Milazzo A, Hall R, Storm PA, Harris RJ, Winslow W, Marmion BP. Sexually transmitted $\mathrm{Q}$ fever. Clin Infect Dis 2001;33(3):399-402. DOI PubMed 
104.Koopmans M, Wilbrink B, Conyn M, Natrop G, van der $\mathrm{Nat} H$, Vennema $\mathrm{H}$, Meijer $\mathrm{A}$, van Steenbergen J, Fouchier R, Osterhaus A, Bosman A. Transmission of H7N7 avian influenza $A$ virus to human beings during a large outbreak in commercial poultry farms in the Netherlands. Lancet 2004;363(9409):587-93. DOI PubMed

105. Cooper ED, Debboun M. The relevance of rabies to today's military. US Army Med Dep J 2012 Jul-Sep;4-11. PubMed

106. Centers for Disease Control and Prevention (CDC). Imported human rabies in a U.S. Army soldier - New York, 2011. MMWR Morb Mortal Wkly Rep 2012;61(17):302-5. PubMed

107. Brito MG, Chamone TL, da Silva FJ, Wada MY, Miranda AB, Castilho JG, Carrieri ML, Kotait I, Lemos FL. Antemortem diagnosis of human rabies in a veterinarian infected when handling a herbivore in Minas Gerais, Brazil. Rev Inst Med Trop São Paulo 2011;53(1):39-44. DOI PubMed

108. Powell JC. Evaluating risk: rabies exposure and occupational implications. AAOHN journal 2009;57(11):465-463.

DOI PubMed

109. Castillo C, Naranjo J, Sepúlveda A, Ossa G, Levy H. Hantavirus pulmonary syndrome due to Andes virus in Temuco, Chile: clinical experience with 16 adults. Chest 2001;120(2):548-54. DOl PubMed

110. Cruz CD, Forshey BM, Vallejo E, Agudo R, Vargas J, Blazes DL, Guevara C, Laguna-Torres VA, Halsey ES, Kochel TJ. Novel strain of Andes virus associated with fatal human infection, central Bolivia. Emerg Infect Dis 2012;18(5):750-7. DOl PubMed
111. Martinez VP, Bellomo CM, Cacace ML, Suarez P, Bogni L, Padula PJ. Hantavirus pulmonary syndrome in Argentina, 1995-2008. Emerg Infect Dis 2010;16(12):1853-60.

DOI PubMed

112. Parkes LO, Nguyen TT, Longtin J, Beaudoin MC, Bestman-Smith J, Vinh DC, Boivin G, Loo VG. A Cluster of Three Cases of Hantavirus Pulmonary Syndrome among Canadian Military Personnel. Can J Infect Dis Med Microbiol 2016;2016:2757969. DOI PubMed

113. Torres-Perez F, Wilson L, Collinge SK, Harmon H, Ray C, Medina RA, Hjelle B. Sin Nombre virus infection in field workers, Colorado, USA. Emerg Infect Dis 2010;16(2):308-10. DOI PubMed

114.Jay M, Hjelle B, Davis R, Ascher M, Baylies HN, Reilly K, Vugia D. Occupational exposure leading to hantavirus pulmonary syndrome in a utility company employee. Clin Infect Dis 1996;22(5):841-4. DOI PubMed

115. Haagsma JA, Tariq L, Heederik DJ, Havelaar AH. Infectious disease risks associated with occupational exposure: a systematic review of the literature. Occup Environ Med 2012;69(2):140-6. DOI PubMed

116.Su CP, de Perio MA, Cummings KJ, McCague AB, Luckhaupt SE, Sweeney MH. Case Investigations of Infectious Diseases Occurring in Workplaces, United States, 2006-2015. Emerg Infect Dis 2019;25(3):397-405.

DOI PubMed 